\title{
Effect of Tissue Fixation on the Histochemical Identification of Acid Mucopolysaccharides
}

\author{
Yoichiro SASaI \\ Department of Dermatology,* Tohoku University School of \\ Medicine, Sendai
}

SASAI, Y. Effect of Tissue Fixation on the Histochemical Identification of Acid Mucopolysaccharides. Tohoku J. exp. Med., 1971, 104, (1) 85-91 — Effect of tissue fixation for the histochemical identification of individual acid mucopolysaccharides was investigated by the application of the critical electrolyte concentration concept. Materials used were cock's comb, the femur-tibial joint and costal cartilage of rat, and human umbilical cords. As fixatives, neutral formalin, CPC-formalin and Carnoy's fluid were employed. Model experiments were performed with pure acid mucopolysaccharides. The pattern of the critical electrolyte concentration of each acid mucopolysaccharide in the non-fixed sections bore a close parallel to that in the model experiments. However, there was difference between the non-fixed and the fixed sections concerning the critical electrolyte concentration of each acid mucopolysaccharide. After peptic digestion, the pattern of the critical electrolyte concentration in the fixed sections was similar to that in the non-fixed sections.-_- acid mucopolysaccharide; histochemistry; critical electrolyte concentration; tissue fixation

Although many staining methods have been developed for the demonstration of acid mucopolysaccharides in tissue sections, the identification of individual acid mucopolysaccharides has been unsuccessful except with the enzyme method of Zugibe (1962). However, the enzymes necessary for the method are not readily available.

In general, all polyanions are precipitated by quaternary ammonium salts or alcian blue, and water-insoluble complexes thus formed become soluble in the presence of electrolytes when their concentration is not below a certain critical level (Scott 1960). Using this principle, Scott and Dorling (1965) tried to identify individual acid mucopolysaccharides in tissue sections. Their trials proved the possibility of visualizing selectively individual acid mucopolysaccharides in tissue sections. However, the author's earlier study (Sasai 1970) indicated that there is some difference between the non-fixed and the fixed sections concerning the critical electrolyte concentration of polyanions in amyloid. The present study was designed to investigate on the effect of tissue fixation for the histochemical identification of individual acid mucopolysaccharide by the application of critical electrolyte concentration concept.

Received for publication, November 2, 1970.

* Director: Prof. M. Seiji. 


\section{Materials and Methods}

Tissue preparation. Specimens of the femur-tibial joints and costal cartilage of 5-day-old rats and of cock's comb were taken immediately post mortem. Human umbilical cords were obtained within 15 minutes after birth. Small samples of each specimen were frozen in liquid nitrogen, cut $8 \mu$ in thickness on a cryostat, and mounted on coverslips without an adhesive. Small parts of each sample were fixed for 24 hours in $10 \%$ neutral formalin, $1 \%$ cetylpyridinium chloride in $10 \%$ formalin (CPC-formalin) and Carnoy's fluid, respectively. After fixation, they were frozen in liquid nitrogen, and cut on a cryostat.

Enzyme digestion. Streptomyces hyaluronidase (Amano Pharmaceutical Co., Nagoya, Japan) was dissolved in a $0.02 \mathrm{M}$ acetate buffer at $\mathrm{pH} 5.0$, in a concentration of 30 TRU per $\mathrm{ml}$. Sections were incubated for 1 hour at $40^{\circ} \mathrm{C}$. Chondroitinase ABC (Seikagaku Kogyo Co., Tokyo, Japan) was dissolved in a $0.0025 \mathrm{M}$ tris-HCl buffer at pH 8.0 , in a concentration of $5 \mathrm{U}$ per $0.3 \mathrm{ml}$. Sections were incubated for 2 hours at $37^{\circ} \mathrm{C}$. Pepsin (Nutritional Biochemicals Co., Cleveland, U.S.A.) was dissolved in $0.02 \mathrm{~N} \mathrm{HCl}$, in a concentration of $2 \mathrm{mg}$ per $\mathrm{ml}$. Sections were incubated for 30 minutes at $37^{\circ} \mathrm{C}$.

Staining. Alcian blue was dissolved to make a $0.05 \%$ solution in $0.05 \mathrm{M}$ acetate buffer of $\mathrm{pH}$ 5.8. The solution was distributed in several dye baths and to these magnesium chloride or sodium chloride was added sequentially so as to give the molarities, ranging from 0.05 to $2.0 \mathrm{M}$. Sections were stained for 4 hours in respective dye baths, then rinsed three times for 5 minutes in baths containing the same buffer and the same concentrations of some electrolytes as used for staining. After rinsing, the sections were washed three more times with distilled water in baths for 3 minutes and dehydrated, cleared and mounted.

Model experiments. To observe the pattern of critical electrolyte concentration of individual acid mucopolysaccharides, cellulose acetate membranes were spotted with $1 \%$ solutions of hyaluronic acid, chondroitin sulfate $A, B$ and $C$, heparitin sulfate and heparin. They were dried in air, stained for 1 hour in the alcian blue solution described above, washed rapidly in a large volume of distilled water and dried in air. Sodium salt of hyaluronic acid was obtained from Sigma Chemical Co., St. Louis, U.S.A. Sodium salts of chondroitin sulfate A, B and C were obtained from Seikagaku Kogyo Co., Tokyo, Japan. Barium salt of heparitin sulfate was supplied from Upjohn International Inc., Kalamazoo, U.S.A. Sodium salt of heparin was taken from Wako Pure Chemical Indust., Osaka, Japan.

\section{Results}

\section{Model experiments}

In the absence of salts, all samples tested showed a moderate affinity for alcian blue. As the salt concentrations were raised, the binding of alcian blue to mucopolysaccharides ceased to take place. When magnesium chloride was added to alcian blue solution, the affinity of acid mucopolysaccharides tested for alcian blue disappeared at $0.1 \mathrm{M}$ (hyaluronic acid), $0.6 \mathrm{M}$ (chondroitin sulfate $\mathrm{B}$ and heparitin sulfate), $0.7 \mathrm{M}$ (chondroitin sulfate $\mathrm{A}$ and $\mathrm{C}$ ), and $0.9 \mathrm{M}$ (heparin), respectively. In the case of sodium chloride, an affinity for alcian blue disappeared at $0.2 \mathrm{M}$ (hyaluronic acid), $0.7 \mathrm{M}$ (heparitin sulfate), $0.8 \mathrm{M}$ (chondroitin sulfate $\mathrm{B}$ ), $0.9 \mathrm{M}$ (chondroitin sulfate $\mathrm{A}$ ) and $1.0 \mathrm{M}$ (chondroitin sulfate $\mathrm{C}$ and heparin), respectively. These results are shown in Table 1. 
TABLE 1. An affinity of spots containing acid mucopolysaccharides for alcian blue on cellulose acelate membrane in salt solutions

\begin{tabular}{|c|c|c|c|c|c|c|c|c|c|c|c|c|c|c|}
\hline \multirow{2}{*}{$\begin{array}{c}\text { Acid } \\
\text { mucopolysaccharide }\end{array}$} & \multicolumn{14}{|c|}{ Molarity of $\mathrm{MgCl}_{2}$} \\
\hline & 0.0 & 0.05 & 0.1 & 0.2 & $0 . \overline{3}$ & 0.4 & 0.5 & 0.6 & 0.7 & 0.8 & 0.9 & 1.0 & 1.1 & $\mid 1.2$ \\
\hline $\begin{array}{l}\text { Hyaluronic acid } \\
\text { Chondroitin sulfate A } \\
\text { Chondroitin sulfate B } \\
\text { Chondroitin sulfate C } \\
\text { Heparitin sulfate } \\
\text { Heparin }\end{array}$ & $\begin{array}{l}+ \\
+ \\
+ \\
+ \\
+ \\
+\end{array}$ & $\begin{array}{l}+ \\
+ \\
+ \\
+ \\
+ \\
+\end{array}$ & $\begin{array}{l} \pm \\
+ \\
+ \\
+ \\
+ \\
+\end{array}$ & $\begin{array}{l}- \\
+ \\
+ \\
+ \\
+ \\
+\end{array}$ & $\begin{array}{l}- \\
+ \\
+ \\
+ \\
+ \\
+\end{array}$ & $\begin{array}{l}- \\
+ \\
+ \\
+ \\
+ \\
+\end{array}$ & $\begin{array}{l}- \\
+ \\
+ \\
+ \\
+ \\
+\end{array}$ & $\begin{array}{l}- \\
+ \\
\pm \\
+ \\
\pm \\
+\end{array}$ & $\begin{array}{l}- \\
\pm \\
- \\
\pm \\
- \\
+\end{array}$ & $\begin{array}{l}- \\
- \\
- \\
- \\
- \\
+\end{array}$ & $\begin{array}{l}- \\
- \\
- \\
- \\
- \\
\pm\end{array}$ & $\begin{array}{l}- \\
- \\
- \\
- \\
- \\
-\end{array}$ & $\begin{array}{l}- \\
- \\
- \\
- \\
- \\
-\end{array}$ & $\begin{array}{l}- \\
- \\
- \\
- \\
-\end{array}$ \\
\hline \multirow{2}{*}{$\begin{array}{c}\text { Acid } \\
\text { mucopolysaccharide }\end{array}$} & \multicolumn{14}{|c|}{ Molarity of $\mathrm{NaCl}$} \\
\hline & 0.0 & 0.05 & 0.1 & 0.2 & 0.3 & 0.4 & 0.5 & 0.6 & 0.7 & 0.8 & 0.9 & 1.0 & 1.1 & 1.2 \\
\hline $\begin{array}{l}\text { Hyaluronic acid } \\
\text { Chondroitin sulfate A } \\
\text { Chondroitin sulfate B } \\
\text { Chondroitin sulfate C } \\
\text { Heparitin sulfate } \\
\text { Heparin }\end{array}$ & $\begin{array}{l}+ \\
+ \\
+ \\
+ \\
+ \\
+\end{array}$ & $\begin{array}{l}+ \\
+ \\
+ \\
+ \\
+ \\
+\end{array}$ & $\begin{array}{l}+ \\
+ \\
+ \\
+ \\
+ \\
+\end{array}$ & $\begin{array}{l}+ \\
+ \\
+ \\
+ \\
+ \\
+\end{array}$ & $\begin{array}{l} \pm \\
+ \\
+ \\
+ \\
+ \\
+\end{array}$ & $\begin{array}{l}- \\
+ \\
+ \\
+ \\
+ \\
+\end{array}$ & $\begin{array}{l}- \\
+ \\
+ \\
+ \\
+ \\
+\end{array}$ & $\begin{array}{l}- \\
+ \\
+ \\
+ \\
+ \\
+\end{array}$ & $\begin{array}{l}- \\
+ \\
+ \\
+ \\
+ \\
+\end{array}$ & $\begin{array}{l}- \\
+ \\
+ \\
+ \\
\pm \\
+\end{array}$ & $\begin{array}{l}- \\
+ \\
\pm \\
+ \\
- \\
+\end{array}$ & $\begin{array}{l}- \\
\pm \\
- \\
+ \\
- \\
+\end{array}$ & $\begin{array}{l}- \\
- \\
- \\
\pm \\
- \\
\pm\end{array}$ & $\begin{array}{l}- \\
- \\
- \\
- \\
- \\
-\end{array}$ \\
\hline
\end{tabular}

\section{Histological experiments}

The ground substance in the mucoid layer of the non-fixcd cock's comb sections was shown to have a strong affinity for alcian blue in the absence of electrolytes. The affinity weakened in proportion to the increase of electrolyte concentration, and disappeared in the presence of magnesium chloride at $0.2 \mathrm{M}$, and of sodium chloride at $0.4 \mathrm{M}$. When the neutral formalin-fixed sections were used, the affinity of the ground substance reduced at $0.2 \mathrm{M}$ (magnesium chloride) or at $0.5 \mathrm{M}$ (sodium chloride), but persisted at $0.4 \mathrm{M}$ (magnesium chloride) or at $0.6 \mathrm{M}$ (sodium chloride). In the case of the CPC-formalin-fixed or Carnoy's fluid-fixed sections, the patterns of the critical electrolyte concentration was similar to those in the neutral formalin-fixed sections, while the affinity in the former two was stronger than that in the latter. Treatment of the specimens with streptomyces hyaluronidase completely abolished the affinity of the ground substance not only in the nonfixed sections, but also in the fixed sections. On the other hand, when the sections were immersed for 1 hour in a $0.02 \mathrm{M}$ acetate buffer at $\mathrm{pH} 5.0$ without enzyme, the affinity of the ground substance was more or less weak. However, no change was found in the pattern of the critical electrolyte concentrations.

The affinity of the stroma of a human umbilical cord for alcian blue was approximately the same as that of the ground substance in the cock's comb concerning the pattern of the critical electrolyte concentrations.

The matrix of the articular and costal cartilages was shown to have a strong affinity for alcian blue. When sections were immersed in the alcian blue solutions containing different concentrations of magnesium chloride from 0.05 to $0.7 \mathrm{M}$, or of sodium chloride from 0.05 to $0.9 \mathrm{M}$, no difference was found in the affinity in either the non-fixed or the fixed sections. The affinity in the non-fixed sections was 
reduced in the presence of magnesium chloride at $0.6 \mathrm{M}$ and disappeared at $0.8 \mathrm{M}$. When sodium chloride was added to the alcian blue solution, the affinity was reduced at 1.0 M and disappeared at 1.1 M. In the case of the neutral formalin- or CPC-formalin-fixed sections, the affinity was reduced in the presence of magnesium chloride at $0.6 \mathrm{M}$, or of the sodium chloride at $1.0 \mathrm{M}$, and disappeared in the presence of magnesium chloride at $0.9 \mathrm{M}$, or of sodium chloride at $1.4 \mathrm{M}$. The affinity in the Carnoy's fluid-fixed sections disappeared in the presence of magnesium chloride at $0.8 \mathrm{M}$, or of sodium chloride at $1.2 \mathrm{M}$. Chondroitinase ABC digestion completely abolished the affinity in both non-fixed and the fixed sections. Immersion in tris- $\mathrm{HCl}$ buffer at $\mathrm{pH} 8.0$ for 1 hour did not affect the affinity in each section tested. When the fixed sections were incubated in the pepsin solution, the affinity practically disappeared in the presence of magnesium

TABle 2. An effect of tissue fixation to an affinity of cock's comb ground substance for alcian blue in salt solutions

\begin{tabular}{|c|c|c|c|c|c|c|c|c|c|c|c|c|c|}
\hline \multirow{2}{*}{ Fixation } & \multicolumn{13}{|c|}{ Molarity of $\mathrm{MgCl}_{2}$} \\
\hline & 0.0 & $\mid 0.05$ & 0.1 & $\mid 0.15$ & 0.2 & 0.25 & 0.3 & 0.35 & 0.4 & 0.5 & & & \\
\hline $\begin{array}{l}\text { Non } \\
\text { Neutral formalin } \\
\text { CPC-formalin } \\
\text { Carnoy's fluid }\end{array}$ & $\begin{array}{l}H \\
H \\
H \\
H\end{array}$ & $\begin{array}{l}H \\
H \\
H \\
H\end{array}$ & $\begin{array}{l}\text { H } \\
H \\
H \\
H\end{array}$ & $\begin{array}{l}H \\
H \\
H \\
H\end{array}$ & $\begin{array}{l}- \\
+ \\
H \\
H\end{array}$ & $\begin{array}{l}- \\
+ \\
H \\
H\end{array}$ & $\begin{array}{l}- \\
+ \\
+ \\
+\end{array}$ & $\begin{array}{l}- \\
+ \\
+ \\
+\end{array}$ & $\begin{array}{l}- \\
- \\
- \\
-\end{array}$ & $\begin{array}{l}- \\
- \\
- \\
-\end{array}$ & & & \\
\hline \multirow{2}{*}{ Fixation } & \multicolumn{13}{|c|}{ Molarity of $\mathrm{NaCl}$} \\
\hline & 0.0 & 0.05 & 0.1 & 0.15 & 0.2 & 0.25 & 0.3 & 0.35 & 0.4 & $\mid 0.5$ & 0.6 & 0.7 & 0.8 \\
\hline $\begin{array}{l}\text { Non } \\
\text { Neutral formalin } \\
\text { CPC-formalin } \\
\text { Carnoy's fluid }\end{array}$ & $\begin{array}{l}H \\
H \\
H \\
H\end{array}$ & $\begin{array}{l}H \\
H \\
H \\
H\end{array}$ & $\begin{array}{l}\text { H } \\
H \\
H \\
H\end{array}$ & $\begin{array}{l}H \\
H \\
H \\
H\end{array}$ & $\begin{array}{l}H \\
H \\
H \\
H\end{array}$ & $\begin{array}{l}\mathrm{H} \\
\mathrm{H} \\
\mathrm{HH} \\
\mathrm{H}\end{array}$ & $\left|\begin{array}{c}H \\
H \\
H \\
H\end{array}\right|$ & $\left|\begin{array}{c}H \\
+ \\
+ \\
H\end{array}\right|$ & $\begin{array}{l}- \\
+ \\
H \\
H\end{array}$ & $\begin{array}{l}- \\
+ \\
+ \\
+\end{array}$ & $\begin{array}{l}- \\
+ \\
+ \\
+\end{array}$ & $\begin{array}{l}- \\
- \\
- \\
-\end{array}$ & $\begin{array}{l}- \\
- \\
- \\
-\end{array}$ \\
\hline
\end{tabular}

TABLE 3. An effect of tissue fixation to an affinity of costal cartilage matrix for alcian blue in salt solutions

\begin{tabular}{|c|c|c|c|c|c|c|c|c|c|c|c|c|c|c|c|}
\hline \multirow{2}{*}{ Fixation } & \multicolumn{15}{|c|}{ Molarity of $\mathrm{MgCl}_{2}$} \\
\hline & 0.0 & 0.1 & 0.2 & 0.3 & 0.4 & 0.5 & 0.6 & 0.7 & 0.8 & 0.9 & 1.0 & 1.1 & \multicolumn{3}{|l|}{1.2} \\
\hline $\begin{array}{l}\text { Non } \\
\text { Neutral formalin } \\
\text { CPC-formalin } \\
\text { Carnoy's fluid }\end{array}$ & $\begin{array}{l}\text { W } \\
\text { H } \\
\text { H } \\
\text { H }\end{array}$ & $\begin{array}{l}\text { W } \\
\text { H } \\
\text { W } \\
\text { H }\end{array}$ & $\begin{array}{l}\# \\
\# \\
H \\
H\end{array}$ & $\begin{array}{l}\text { WH } \\
\text { HI } \\
\text { HI } \\
\text { HI }\end{array}$ & $\begin{array}{l}H \\
W \\
H \\
H\end{array}$ & $\begin{array}{l}\text { W } \\
\text { Ht } \\
\text { W } \\
\text { Ht }\end{array}$ & $\begin{array}{l}H \\
H \\
H \\
H\end{array}$ & $\begin{array}{l}H \\
H \\
H \\
H\end{array}$ & $\begin{array}{l}- \\
+ \\
+ \\
-\end{array}$ & $\begin{array}{l}- \\
+ \\
+ \\
-\end{array}$ & $\begin{array}{l}- \\
- \\
- \\
-\end{array}$ & $\begin{array}{l}- \\
- \\
- \\
-\end{array}$ & $\begin{array}{l}- \\
- \\
- \\
-\end{array}$ & & \\
\hline \multirow{2}{*}{ Fixation } & \multicolumn{15}{|c|}{ Molarity of $\mathrm{NaCl}$} \\
\hline & 0.0 & 0.1 & 0.2 & 0.3 & 0.4 & 0.5 & 0.6 & 0.7 & 0.8 & 0.9 & 1.0 & 1.1 & 1.2 & 1.3 & 1.4 \\
\hline $\begin{array}{l}\text { Non } \\
\text { Neutral formalin } \\
\text { CPC-formalin } \\
\text { Carnoy's fluid }\end{array}$ & $\begin{array}{l}\text { W } \\
\text { H } \\
\text { WH } \\
\text { Ht }\end{array}$ & $\begin{array}{l}\text { \# } \\
\text { W } \\
\text { \# } \\
\text { m }\end{array}$ & $\begin{array}{l}\text { H } \\
H \\
H \\
H\end{array}$ & $\begin{array}{l}\text { H } \\
\text { W } \\
\text { W } \\
\text { H }\end{array}$ & $\begin{array}{l}\text { H } \\
\text { W } \\
\text { H } \\
\text { Ht }\end{array}$ & $\begin{array}{l}\text { W } \\
\text { H } \\
\text { H } \\
\text { H }\end{array}$ & $\begin{array}{l}\text { \# } \\
\text { W } \\
\text { H } \\
\text { H }\end{array}$ & $\begin{array}{l}\text { H } \\
\text { H } \\
\text { H } \\
\text { H }\end{array}$ & $\begin{array}{l}\text { W } \\
\text { W } \\
\text { W } \\
\text { W }\end{array}$ & $\begin{array}{l}\text { H } \\
\text { H } \\
\text { H } \\
\text { HI }\end{array}$ & $\begin{array}{l}+ \\
+ \\
+ \\
+\end{array}$ & $\begin{array}{l}- \\
+ \\
+ \\
+\end{array}$ & $\begin{array}{l}- \\
+ \\
+ \\
-\end{array}$ & $\begin{array}{l}- \\
+ \\
+ \\
-\end{array}$ & $\begin{array}{l}- \\
- \\
- \\
-\end{array}$ \\
\hline
\end{tabular}


TABLE 4. An effect of peptic digestion to an affinity of cock's comb ground substance for alcian blue in salt solutions

\begin{tabular}{|c|c|c|c|c|c|c|c|c|c|c|c|c|c|}
\hline \multirow{2}{*}{ Fixation } & \multicolumn{13}{|c|}{ Molarity of $\mathrm{MgCl}_{2}$} \\
\hline & 0.0 & 0.05 & 0.10 & 0.15 & 0.2 & 0.25 & 0.3 & $|0.35|$ & 0.4 & \multicolumn{4}{|l|}{0.5} \\
\hline $\begin{array}{l}\text { Non } \\
\text { Neutral formalin } \\
\text { CPC-formalin } \\
\text { Carnoy's fluid }\end{array}$ & $\begin{array}{l}H+H \\
H \\
H \\
H\end{array}$ & $\left|\begin{array}{l}H \\
H \\
H \\
H\end{array}\right|$ & $\begin{array}{l}H \\
H \\
H \\
H\end{array}$ & $\begin{array}{l}H \\
H \\
H \\
H\end{array}$ & $\left|\begin{array}{c}- \\
+ \\
+ \\
+\end{array}\right|$ & $\begin{array}{l}- \\
- \\
- \\
+\end{array}$ & $\begin{array}{l}- \\
- \\
- \\
-\end{array}$ & $\left|\begin{array}{l}- \\
- \\
- \\
-\end{array}\right|$ & $\begin{array}{l}- \\
- \\
- \\
-\end{array}$ & \multicolumn{4}{|l|}{$\mid \begin{array}{l}- \\
- \\
- \\
-\end{array}$} \\
\hline \multirow{2}{*}{ Fixation } & \multicolumn{13}{|c|}{ Molarity of $\mathrm{NaCl}$} \\
\hline & 0.0 & 0.05 & 0.1 & 0.15 & $\mid 0.2$ & 0.25 & 0.3 & 0.35 & 0.4 & 0.5 & 0.6 & 0.7 & 0.8 \\
\hline $\begin{array}{l}\text { Non } \\
\text { Neutral formalin } \\
\text { CPC-formalin } \\
\text { Carnoy's fluid }\end{array}$ & $\begin{array}{l}\text { H } \\
H \\
H \\
H\end{array}$ & $\begin{array}{l}H \\
H \\
H \\
H\end{array}$ & $\begin{array}{l}\text { W } \\
H \\
H \\
H\end{array}$ & $\begin{array}{l}H \\
H \\
H \\
H\end{array}$ & $\begin{array}{l}H \\
H \\
H \\
H\end{array}$ & $\begin{array}{c}H \\
H \\
H \\
H\end{array}$ & $\begin{array}{l}H \\
H \\
H \\
H\end{array}$ & $\begin{array}{l}H \\
H \\
H \\
H\end{array}$ & $\begin{array}{l}- \\
+ \\
+ \\
+\end{array}$ & $\begin{array}{l}- \\
- \\
- \\
+\end{array}$ & $\begin{array}{l}- \\
- \\
- \\
-\end{array}$ & $\begin{array}{l}- \\
- \\
- \\
-\end{array}$ & $\begin{array}{l}- \\
- \\
- \\
-\end{array}$ \\
\hline
\end{tabular}

TABLE 5. An effect of peptic digestion to an affinity of costal cartilage matrix for alcian blue in salt solutions

\begin{tabular}{|c|c|c|c|c|c|c|c|c|c|c|c|c|c|c|c|}
\hline \multirow{2}{*}{ Fixation } & \multicolumn{15}{|c|}{ Molarity of $\mathrm{MgCl}_{2}$} \\
\hline & 0.0 & 0.1 & 0.2 & 0.3 & 0.4 & 0.5 & $\mid 0.6$ & 0.7 & 0.8 & 0.9 & $\mid 1.0$ & 1.1 & 1.2 & & \\
\hline $\begin{array}{l}\text { Non } \\
\text { Neutral formalin } \\
\text { CPC-formalin } \\
\text { Carnoy's fluid }\end{array}$ & $\begin{array}{c}\text { H } \\
H \\
+H \\
H\end{array}$ & $\begin{array}{l}\text { \# } \\
\text { H } \\
\text { H } \\
\text { HI }\end{array}$ & $\begin{array}{l}\text { H } \\
\text { H } \\
\text { H } \\
+11\end{array}$ & $\begin{array}{l}H+1 \\
H \\
H \\
H\end{array}$ & $\begin{array}{l}\text { W } \\
\text { W } \\
\text { W } \\
\text { HI }\end{array}$ & $\begin{array}{l}\text { H } \\
\mathrm{H} \\
\mathrm{H} \\
\mathrm{H}\end{array}$ & $\begin{array}{l}H \\
H \\
H \\
H\end{array}$ & $\begin{array}{l}H \\
H \\
H \\
H\end{array}$ & $\begin{array}{l}- \\
+ \\
+ \\
-\end{array}$ & $\begin{array}{l}- \\
- \\
- \\
-\end{array}$ & $\begin{array}{l}- \\
- \\
- \\
-\end{array}$ & $\begin{array}{l}- \\
- \\
- \\
-\end{array}$ & $\begin{array}{l}- \\
- \\
- \\
-\end{array}$ & & \\
\hline \multirow{2}{*}{ Fixation } & \multicolumn{15}{|c|}{ Molarity of $\mathrm{NaCl}$} \\
\hline & 0.0 & 0.1 & 0.2 & 0.3 & 0.4 & 0.5 & $|0.6|$ & 0.7 & 0.8 & 0.9 & 1.0 & 1.1 & $\mid 1.2$ & 1.3 & 1.4 \\
\hline $\begin{array}{l}\text { Non } \\
\text { Neutral formalin } \\
\text { CPC-formalin } \\
\text { Carnoy's fluid }\end{array}$ & $\begin{array}{l}\text { \# } \\
\text { \# } \\
\text { W } \\
\text { H }\end{array}$ & $\begin{array}{l}\text { H } \\
\text { H } \\
\text { H } \\
\text { H }\end{array}$ & $\begin{array}{l}\text { H } \\
\text { H } \\
\mathrm{H} \\
\mathrm{H}\end{array}$ & $\begin{array}{l}H \\
H \\
H \\
H\end{array}$ & $\begin{array}{l}\text { H } \\
\text { H } \\
H \\
H\end{array}$ & $\begin{array}{l}\text { W } \\
\text { H } \\
\text { H } \\
H\end{array}$ & $\begin{array}{c}\text { H } \\
+W \\
+ \\
H\end{array}$ & $\begin{array}{l}+\# \\
H \\
m \\
m\end{array}$ & $\begin{array}{l}\text { H } \\
\text { H } \\
\text { Ht } \\
\mathrm{Ht}\end{array}$ & $\begin{array}{c}\text { W } \\
H \\
H \\
H\end{array} \mid$ & $\begin{array}{l}+ \\
+ \\
+ \\
+\end{array}$ & $\begin{array}{l}- \\
+ \\
+ \\
+\end{array}$ & $\begin{array}{l}- \\
- \\
- \\
-\end{array}$ & $\begin{array}{l}- \\
- \\
- \\
-\end{array}$ & $\begin{array}{l}- \\
- \\
- \\
-\end{array}$ \\
\hline
\end{tabular}

chloride at $0.9 \mathrm{M}$, or of sodium chloride at 1.2 M. In the case of the non-fixed sections, peptic digestion failed to change the affinity. These results are summarized in Tables 2-5.

\section{Discussion}

In precise histological studies concerning the relationship of acid mucopolysaccharides to function, there is a need for histochemical methods to distinguish individual acid mucopolysaccharides in tissue sections. Scott's critical electrolyte concentration concept (1960) led to the development of new histochemical methods for their identification: the cethylpyridinium chloride-toluidine blue method of Kelly, Bloom and Scott (1963); the acridine orange method of Saunders (1964); the alcian blue-magnesium chloride method of Scott and Dorling (1965); 
and the ion association-fractionation method of Zugibe and Fink (1966). By the practical application of these methods, however, some workers (Sano 1965, Watanabe 1970) observed that the critical electrolyte concentration at which a polyanion ceases to stain is not sharply defined on the histological preparations. And, the author's earlier study (Sasai 1970) indicated that there was some difference between the non-fixed and the fixed sections concerning the critical electrolyte concentration of each acid mucopolysaccharide contained in amyloid.

In the present study, the pattern of the critical electrolyte concentration of each acid mucopolysaccharide in the non-fixed sections was similar to that in the model experiments, although the former was about $30 \%$ higher than the latter. This seems to be due to a variety of factors, e.g., that molecular weight of each acid mucopolysaccharide in the tissue which will certainly be higher, and that concentration in the tissue which is many times greater (Scott 1968). On the other hand, the pattern of critical electrolyte concentrations in the fixed sections was not entirely the same as that in the non-fixed sections. In the fixed sections, the affinity of each acid mucopolysaccharide for alcian blue was strikingly reduced but did not disappear in the presence of electrolytes at the concentration which was the same level as the critical electrolyte concentration of the non-fixed sections. The affinity in the presence of electrolyte at a concentration higher than the critical concentration disappeared completely by the treatment with streptomyces hyaluronidase or chondroitinase $A B C$ in the case of the non-fixed sections. Hyaluronidase from Streptomyces hyalurolyticus degrades only hyaluronic acid (Ohya and Kaneko 1970), and chondroitinase ABC from Proteus vulgaris degrades chondroitin sulfate A,B and C (Yamagata et al. 1968). Accordingly, the above results indicate that the elution of acid mucopolysaccharides from the tissue sections at each critical electrolyte concentration will be prevented by a fixation procedure in the case of fixed sections.

Fixation as a histological term is required for immobilization of the metabolic events and their substrates, preservation of the spatial relationship of the cell and tissue components, prevention of physical, chemical and autolytic artefacts. Many fixatives in current use are directed towards tissue proteins. In the native state, most of the acid mucopolysaccharides occur as covalent complexes with proteins. That the pattern of critical electrolyte concentrations in the fixed sections approaches that in the non-fixed sections may suggest that a protein precipitation from the fixation procedure is related to the prevention of the elution of acid mucopolysaccharides.

\section{References}

1) Kelly, J.W., Bloom, G.D. and Scott, J.E. Quaternary ammonium compounds in connective tissue histochemistry. I. Selective unblocking. $J$. Histochem. Cytochem., 1963, 11, 791-798.

2) Ohya, T. \& Kaneko, Y. Novel hyaluronidase from Streptomyces. Biochim. biophys. Acta (Amst.), 1970, 198, 607-609. 
3) Sano, S. Biochemical and histochemical studies on the acid mucopolysaccharides in the skin. Jap. J. Derm., Ser. B, 1965, 75, 536-538.

4) Sasai, Y. Histochemical study of acid mucopolysaccharides in lichen amyloidosus. Tohoku J. exp. Med, 1970, 102, 185-193.

5) Saunders, A.M. Histochemical identification of acid mucopolysccharides with acridine orange. J. Histochem. Cytochem., 1964, 12, 164-170.

6) Scott, J.E. Aliphatic ammonium salts in the assay of acidic polysaccharides from tissues. In: Methods of Biochemical Analysis, vol. 8, edited by D. Glick, Interscience Publishers, New York, 1960, p. 145.

7) Scott, J.E. Patterns of specificity in the interaction of organic cations with acid mucopolysaccharides. In: The Chemical Physiology of Mucopolysaccharides, edited by G. Quintarelli, Little, Brown and Co., Boston, 1968, p. 219.

8) Scott, J.E. and Dorling, J. Differential staining of acid glycosaminoglycans (mucopolysaccharides) by alcian blue in salt solutions. Histochemie, 1965, 5, 221-233.

9) Watanabe, Y. Studies on some fundamental problems of the histochemical demonstration of acid mucopolysaccharides. Connective Tissue, 1970, No. 2, 27-66.

10) Yamagata, T., Saito, H., Habuchi, O. \& Suzuki, S. Purification and properties of bacterial chondroitinase and chondrosulfatase. J. biol. Chem., 1968, 243, 15231535 .

11) Zugibe, F.T. The demonstration of the individual acid mucopolysaccharides in human aortas, coronary arteries and cerebral arteries. I. The methods. J. Histochem. Cytochem., 1962, 10, 441-447.

12) Zugibe, F.T. and Fink, M.L.(a) A new ion association technique for demonstrating polyanions in tissue sections. J. Histochem. Cytochem., 1966, 14, 144-152.

13) Zugibe, F.T. and Fink, M.L. (b) A new ion association-fractionation technique for identifying individual mucopolysaccharides and other polyanions in tissue sections. J. Histochem. Cytochem., 1966, 14, 153-158. 